\title{
A systematic review of drug induced ocular reactions in diabetes
}

\author{
J P Hampson, J N Harvey
}

\begin{abstract}
Aims-To conduct a systematic review of drug induced adverse ocular effects in diabetes to determine if this approach identified any previously unrecognised adverse drug effects; to make a preliminary assessment of the feasibility of this approach in identifying adverse drug reactions; and to assess the current accessibility of this information to prescribing physicians.
\end{abstract}

Methods-Literature search of online biomedical databases. The search strategy linked eye disorders with adverse drug reactions and diabetes. Source journals were classified as medical, pharmaceutical, diabetes related, or ophthalmological. It was determined whether the reactions identified were recorded in drug datasheets and the British National Formulary.

Results-63 references fulfilled the selection criteria, of which 45 were considered to be relevant to the study. The majority of these were case reports but cross sectional surveys, case-control and cohort studies, and review articles were also identified. $61 \%$ of the reactions were not recorded in the British National Formulary and $41 \%$ were not recorded in the datasheets. $55 \%$ appeared in specialist ophthalmology journals.

Conclusions-This is a feasible approach to the identification of adverse drug reactions. Adverse reactions not listed in the most commonly used reference sources were found. The majority were published in specialist ophthalmology journals which might not be seen by prescribing physicians.

(Br F Ophthalmol 2000;84:144-149)

Diabetes is associated with a variety of ocular manifestations and is a major cause of visual impairment. ${ }^{12}$ Thus, the recognition or anticipation of adverse drug reactions involving the eye is important. However, drug induced ocular side effects are uncommon. Measurements of prevalence are difficult to do and precise estimates are generally unavailable. The data which do exist rely on the astute physician making a connection between an eye condition and the patient's systemic therapy. In the USA, data on all drug induced ocular side effects can be obtained from the National Registry of Drug Induced Ocular Side Effects. ${ }^{3}$ It is postulated that, as a result of this registry, ocular adverse effects are identified earlier and patients protected. In the UK, to the authors' knowledge, there is no such equivalent. The Committee on Safety of Medicines (CSM) holds data on all adverse drug reactions, but not specifically on those related to the eye. General physicians must rely on their personal knowledge, official warnings, and the range of journals which they read regularly to help them identify and manage suspected reactions. Two of the most readily accessed information sources are the British National Formulary $(B N F)$ and the Summary of Product Characteristics (SPCs), formerly known as datasheets. ${ }^{45}$ However, the possibility that the majority of ocular reactions are reported only in specialist ophthalmology journals reduces the chance of general physicians being aware of some important adverse drug effects.

The purpose of this study was to systematically review the world literature on drug induced ocular side effects in diabetes. Ultimately, a list of drugs and side effects would be produced to aid general physicians in identification of such reactions. This systematic review strategy has not previously been applied to adverse drug reactions and thus a secondary aim was to assess the feasibility of this approach to drug reactions in a clinical area of manageable size. We also wanted to determine whether these adverse reactions were to be found in the standard reference sources - that is, the $B N F$ and SPC, and to look at the type of journals where they were reported in order to assess accessibility to this kind of information.

\section{Methods}

LITERATURE REVIEW

An online literature search of the databases Medline, Embase, Biosis, Toxline, Pharmline, IOWA, and International Pharmaceutical Abstracts was performed towards the end of June 1998. The search strategy (available from the authors) principally linked eye disorders with adverse drug reactions and was narrowed down by adding the term "diabetes". Criteria for selection of titles produced by the search included the presence of a commonly prescribed drug name and ocular effect in the title. Animal studies were excluded. Titles fulfilling these criteria were downloaded and the full reference obtained where possible. In a small number of cases, for foreign journals, the English abstract was used. If no English translation was available the article was excluded. On scanning the full reference the corresponding author of any article thought to be of value published in the past 10 years was contacted to determine whether they had additional data on similar or other work (published or unpublished). A search of the Cochrane Database
Accepted for publication 27 July 1999 
Table 1 Case reports of drug induced ocular toxicity

\begin{tabular}{|c|c|c|c|c|c|}
\hline Author (year) & Drug & Adverse reaction & Population & Intervention and outcome & Comments \\
\hline Miller $^{13}(1978)$ & Chlorothiazide & $\begin{array}{l}\text { Oculomotor nerve } \\
\text { palsy }\end{array}$ & $\begin{array}{l}47 \text { year old male. GTT } \\
\text { abnormal on thiazide } \\
\text { treatment }\end{array}$ & $\begin{array}{l}7 \text { months of diuretic for nephrolithiasis. } \\
3 \text { days' history of orbital pain and ptosis. } \\
\text { Diuretic stopped, } 3 / 12 \text { later, palsy } \\
\text { resolved and } 2 \text { GTTS were normal }\end{array}$ & $\begin{array}{l}\text { No rechallenge but all other } \\
\text { causes of palsy ruled out. } \\
\text { Proposed mechanism of } \\
\text { glucose intolerance induced } \\
\text { microangiopathy }\end{array}$ \\
\hline Sponsel $^{14}(1992)$ & Indapamide & Bilateral cataracts & $\begin{array}{l}39 \text { year old male. } \\
\text { Hypertensive and obese }\end{array}$ & $\begin{array}{l}31 / 2 \text { years of indapamide. } \\
\text { Hyperglycaemia with reduced visual } \\
\text { acuity and colour vision changes. } \\
\text { Stopping therapy halted progression of } \\
\text { visual disturbances }\end{array}$ & $\begin{array}{l}\text { No rechallenge but no other } \\
\text { risk factors for cataracts. } \\
\text { Surgery required for cataracts }\end{array}$ \\
\hline Wymore $^{15}(1982)$ & Chlorpropamide & Optic neuropathy & $\begin{array}{l}65 \text { year old male. NIDDM } \\
\text { for } 1 \text { year }\end{array}$ & $\begin{array}{l}\text { Reduced visual acuity after } 1 \text { year of } \\
\text { treatment. Dramatic improvement in } \\
\text { visual acuity and colour vision on } \\
\text { stopping drug }\end{array}$ & $\begin{array}{l}\text { Rechallenge for } 5 \text { days } \\
\text { showed reduced visual acuity. } \\
\text { Vision returned to baseline } \\
\text { after stopping }\end{array}$ \\
\hline $\mathrm{D}^{\prime} \operatorname{Arcy}^{16}(1989)$ & Glibenclamide & Myopia & 35 year old male & $\begin{array}{l}\text { Symptomatic after } 2 \text { days of } \\
\text { glibenclamide. Vision returned to } \\
\text { normal } 3 \text { days after discontinuation }\end{array}$ & $\begin{array}{l}\text { No rechallenge. Patient } \\
\text { remained on diet control for } \\
\text { diabetes }\end{array}$ \\
\hline $\begin{array}{l}\text { Lightman }^{17} \\
\quad(1989)\end{array}$ & $\begin{array}{l}\text { Glyburide } \\
\text { (Glibenclamide) }\end{array}$ & $\begin{array}{l}\text { (1) Hyperopia } \\
\text { (2) crystalline lens } \\
\text { deposits }\end{array}$ & $\begin{array}{l}66 \text { year old male. New case } \\
\text { of NIDDM }\end{array}$ & $\begin{array}{l}\text { Osmotic effects thought to be cause of } \\
\text { lens changes }\end{array}$ & $\begin{array}{l}\text { No rechallenge. Alternative } \\
\text { explanation proposed by } \\
\text { Keller }^{45}\end{array}$ \\
\hline Hamill $^{18}(1983)$ & $\begin{array}{l}\text { Scopolamine } \\
\text { (Transdermal) }\end{array}$ & $\begin{array}{l}\text { Acute angle } \\
\text { closure glaucoma }\end{array}$ & $\begin{array}{l}58 \text { year male. NIDDM and } \\
\text { hypertensive on methyl } \\
\text { dopa and propranolol }\end{array}$ & $\begin{array}{l}\text { Intraocular pressure }>80 \mathrm{~mm} \mathrm{Hg} \text { after } 4 \\
\text { days of patch treatment. Probably } \\
\text { unrelated to diabetes }\end{array}$ & $\begin{array}{l}\text { No rechallenge. Predictable } \\
\text { from pharmacology }\end{array}$ \\
\hline Sedwick $^{19}(1992)$ & Amiodarone & Optic neuropathy & $\begin{array}{l}62 \text { year old male. } \\
\text { Hypertensive with NIDDM } \\
\text { on diazide and glyburide }\end{array}$ & $\begin{array}{l}\text { Sudden visual loss when given } \\
\text { amiodarone. Bilateral optic neuropathy }\end{array}$ & $\begin{array}{l}\text { Vision improved after } \\
\text { stopping amiodarone. After } 3 \\
\text { weeks of rechallenge, vision } \\
\text { deteriorated }\end{array}$ \\
\hline $\begin{array}{l}\text { Zenimaru }{ }^{20} \\
(1997)^{\star}\end{array}$ & Interferon & $\begin{array}{l}\text { Worsening of } \\
\text { retinopathy }\end{array}$ & $\begin{array}{l}38 \text { year old male. Diabetic } \\
\text { with hepatitis C }\end{array}$ & $\begin{array}{l}\text { Development of retinopathy with } \\
\text { massive vitreous haemorrhages after } 9 \\
\text { months }\end{array}$ & $\begin{array}{l}\text { Vitreous haemorrhage } \\
\text { required surgery. No } \\
\text { rechallenge }\end{array}$ \\
\hline $\operatorname{Dukar}^{26}(1993)$ & $\mathrm{OKT}_{3}$ & Retinal toxicity & $\begin{array}{l}\text { Two post-renal transplant } \\
\text { females. One had IDDM }\end{array}$ & $\begin{array}{l}\text { Case 1: reduced visual acuity after } 1 \\
\text { week of } \mathrm{OKT}_{3} \text {. Cataract extraction } 2 \\
\text { years later. Repeat } \mathrm{OKT}_{3} \text { resulted in } \\
\text { vision loss. Case } 2: \mathrm{OKT}_{3} \text { for kidney } \\
\text { rejection resulted in total loss in vision } \\
\text { after } 2 \text { nd dose }\end{array}$ & $\begin{array}{l}\text { Rechallenge in case } 1 . \text { No } \\
\text { other reason for vision loss } \\
\text { apart from slight narrowing of } \\
\text { retinal vessels }\end{array}$ \\
\hline $\begin{array}{l}\text { Flipovic }^{21} \\
\quad(1997)^{\star}\end{array}$ & Ethambutol & Optic neuropathy & Series of cases & Few details available & \\
\hline $\begin{array}{l}\text { Sorensen } \\
\quad(1977)\end{array}$ & $\begin{array}{l}\text { Phenformin }+ \\
\text { ethanol }\end{array}$ & $\begin{array}{l}\text { Retinal } \\
\text { dysfunction }\end{array}$ & $\begin{array}{l}57 \text { year female. Diabetic } \\
\text { and obese. Following } \\
\text { alcohol binge }\end{array}$ & $\begin{array}{l}\text { Severe reduction in visual acuity. } \\
\text { Blindness improved with intensive } \\
\text { treatment for lactic acidosis }\end{array}$ & $\begin{array}{l}\text { No rechallenge. Possible } \\
\text { mechanism is inhibition of } \\
\text { oxidative metabolism }\end{array}$ \\
\hline Maddox $^{23}(1977)$ & Warfarin & $\begin{array}{l}\text { Retinal and } \\
\text { vitreous } \\
\text { haemorrhages }\end{array}$ & $\begin{array}{l}\text { Female diabetic underwent } \\
\text { mitral valvotomy }\end{array}$ & $\begin{array}{l}\text { Given warfarin } 11 \mathrm{mg} \text {. After } 1 \text { year } \\
\text { haemorrhaged into both eyes resulting } \\
\text { in blindness }\end{array}$ & No recovery. No rechallenge \\
\hline $\begin{array}{l}\text { Caramelli24 }^{24} \\
\quad(1991)\end{array}$ & Streptokinase & $\begin{array}{l}\text { Retinal and } \\
\text { vitreous } \\
\text { haemorrhage }\end{array}$ & $\begin{array}{l}46 \text { year old diabetic male } \\
\text { with } 3 \text { years proliferative } \\
\text { retinopathy. Given } \\
\text { streptokinase for } \mathrm{MI}\end{array}$ & $\begin{array}{l}\text { Marked reduction in vision with some } \\
\text { recovery. Cardiac status felt to have } \\
\text { benefited from thrombolysis }\end{array}$ & $\begin{array}{l}\text { No rechallenge. Vision } \\
\text { improved without further } \\
\text { treatment }\end{array}$ \\
\hline $\begin{array}{l}\text { Jimenez-Lucho }{ }^{25} \\
\quad(1987)\end{array}$ & Isoniazid & Optic neuropathy & $\begin{array}{l}71 \text { year old. Also on } \\
\text { ethambutol, pyridoxine, } \\
\text { nifedipine, and allopurinol }\end{array}$ & $\begin{array}{l}\text { Reduced visual acuity after } 7 \text { months of } \\
\text { TB treatment. Greatest improvement } \\
\text { after stopping isoniazid. }\end{array}$ & No rechallenge \\
\hline
\end{tabular}

^Indicates data obtained from abstract.

was also performed. ${ }^{6}$ Data from every relevant article were extracted in a systematic format. Data extracted included study type, drug prescribed, details of adverse reaction and population, randomisation, study blindness, inclusion/exclusion criteria, statistical significance and power, follow up, and generalisability. Using this information, a comprehensive list of drugs and their suspected effects on the eye was produced.

JOURNAL CATEGORY

The journal type from all of the articles used in the review were categorised as medical (general or specialist), pharmaceutical, diabetes related, or ophthalmological. The proportion of each type was calculated.

BNF AND SPC AGREEMENT WITH REVIEW LIST

Using the list above, the side effects were crosschecked in the BNF and SPC. Each adverse reaction was classified as (A) present in both sources, (B) partial agreement, or (C) present in review list only. Partial agreement was defined as when the $B N F$ or SPC contained a phrase which did not precisely define the reaction in question-for example, visual disturbance was in partial agreement with short sightedness.

\section{Results}

The electronic search produced a total of 528 titles for further assessment. Sixty three references were identified using the selection criteria, and 45 full references were eventually selected as being relevant to the study. These included four articles available in abstract only and six review articles. ${ }^{7-12}$ The majority of studies were case reports (Table 1). ${ }^{13-26}$ The other articles consisted of cross sectional, cohort, and case-control studies (Table 2). ${ }^{27-43}$

SUSPECTED DRUG REACTIONS

References were included in the review when the subjects were diabetic or where diabetes was considered to be one of the confounding factors. Despite "diabetes" being one of the search terms, it was sometimes not clear whether the patient groups did include diabetes. For the purposes of the review, this small number of studies was included where the drug reaction was also mentioned by at 
Table 2 Drug induced ocular side effects: case-control, cohort, and cross sectional studies

\begin{tabular}{|c|c|c|c|c|c|}
\hline Author (year) & Study type & Drug & Adverse reaction & Population intervention and outcome & Comments \\
\hline Lakowski $^{27}(1977)$ & Case-control & $\begin{array}{l}\text { Oral contraceptive } \\
\text { (OC) }\end{array}$ & $\begin{array}{l}\text { Colour vision } \\
\text { alteration }\end{array}$ & $\begin{array}{l}14 \text { diabetic women on OC and } 20 \\
\text { non-diabetic controls. Age matched. } \\
\text { Similar duration of diabetes. All } \\
\text { normal vision, nulliparous and no } \\
\text { retinopathy. Significant }(\mathrm{p}<0.05) \\
\text { red/green deficiency in diabetic OC } \\
\text { users. Subsequent report states main } \\
\text { deficiency in yellow/blue areas }{ }^{44}\end{array}$ & $\begin{array}{l}\text { Small scale-statistical power not } \\
\text { stated. Correlation of deficiency with } \\
\text { duration of diabetes }\end{array}$ \\
\hline $\operatorname{Garg}^{28}(1993)$ & Case-control & $\begin{array}{l}\text { Oral contraceptive } \\
\text { (OC) }\end{array}$ & Retinopathy & $\begin{array}{l}43 \text { cases and controls. Cases all } \\
\text { IDDM ( } 15 \text { years }+ \text { ) and on OC } 1 \\
\text { year. No change in retinopathy grade } \\
\text { over time }\end{array}$ & $\begin{array}{l}\text { Small scale-statistical power not } \\
\text { stated. May be biased because studied } \\
\text { eye clinic attendees only }\end{array}$ \\
\hline Klein $^{29}(1990)$ & Cross sectional & $\begin{array}{l}\text { Oral contraceptive } \\
\text { (OC) }\end{array}$ & Retinopathy & $\begin{array}{l}384 \text { females under age of } 40 \text { all with } \\
\text { IDDM. full medical and eye exam } \\
\text { initially and at } 2 \text { years. No relation } \\
\text { between OC use and degree of } \\
\text { retinopathy. Multiple regression } \\
\text { technique }\end{array}$ & $\begin{array}{l}\text { Small scale-statistical power not } \\
\text { stated. Bias may have occurred } \\
\text { because doctors may not generally } \\
\text { prescribe pill to diabetics }\end{array}$ \\
\hline Greven $^{30}(1995)$ & Cross sectional & $\begin{array}{l}\text { Oral contraceptive } \\
\text { (OC) }\end{array}$ & $\begin{array}{l}\text { Retinal artery } \\
\text { occlusion (RAO) }\end{array}$ & $\begin{array}{l}21 \text { females. Examined all factors } \\
\text { likely to be associated with occlusion. } \\
4 / 21 \text { women on OC. } 2 / 21 \text { had } \\
\text { diabetes }\end{array}$ & No statistical analysis stated \\
\hline Steinberg $^{31}(1996)$ & Cross sectional & Erythropoietin & Hallucinations & $\begin{array}{l}18 \text { dialysis patients on erythropoietin } \\
\text { with hallucinations. Significant } \\
\text { association of hallucinations with } \\
\text { diabetic retinopathy and age }\end{array}$ & $\begin{array}{l}\text { Convenience sample of all dialysis } \\
\text { patients }\end{array}$ \\
\hline $\operatorname{Chen}^{32}(1996)^{\star}$ & Cross sectional & Interferon & Retinopathy & $\begin{array}{l}\text { Chronic active hepatitis patients } \\
(\mathrm{n}=34) .12 / 34 \text { had retinopathy } \\
\text { following interferon which } \\
\text { disappeared on cessation of treatment }\end{array}$ & $\begin{array}{l}\text { Authors postulated that mechanism } \\
\text { due to inherent vascular abnormalities } \\
\text { caused by diabetes }\end{array}$ \\
\hline Kawano $^{33}$ (1996) & Cross sectional & Interferon & Retinopathy & $\begin{array}{l}36 / 63 \text { hepatitis C patients treated } \\
\text { with interferon developed retinal } \\
\text { haemorrhages and soft exudates in } \\
4-8 \text { weeks. } 14 \text { NIDDMs }\end{array}$ & Greatest effect in diabetics \\
\hline $\begin{array}{l}\text { Ramamurthy } \\
\text { (1997) }\end{array}$ & Cross sectional & Urokinase & $\begin{array}{l}\text { Retinal } \\
\text { haemorrhage }\end{array}$ & $\begin{array}{l}20 \text { diabetics on dialysis. Eye } \\
\text { examination before and after } \\
\text { urokinase }\end{array}$ & \\
\hline $\operatorname{Isaac}^{35}(1991)$ & $\begin{array}{l}\text { Retrospective } \\
\text { cohort }\end{array}$ & Phenothiazines & Cataracts & $\begin{array}{l}4674 \text { patients with cataracts. } \\
\text { Matched for age and sex. Used } \\
\text { conditional logistic regression. } \\
\text { Relative incidence of cataract was } 3.5 \\
\text { higher in phenothiazine users of } 3-5 \\
\text { years' duration }\end{array}$ & $\begin{array}{l}\text { Also found steroids and } \\
\text { benzodiazepines increased risk of } \\
\text { cataract }\end{array}$ \\
\hline Clair $^{36}$ (1989) & Case-control & Allopurinol & Cataracts & $\begin{array}{l}\text { From pharmacy records of } \\
\text { allopurinol users. } 51 \text { cases and } 76 \\
\text { controls. Confounders age, sex, } \\
\text { diabetes, and hypertension ruled out } \\
\text { by logistic regression. Risk ration for } \\
\text { cataract of } 1.3 \text { not significant }\end{array}$ & $\begin{array}{l}\text { Potential bias in controls. Selection } \\
\text { based on response to offer of free eye } \\
\text { test, over } 80 \% \text { refused. Cases all had } \\
\text { previous eye examinations }\end{array}$ \\
\hline $\operatorname{Liu}^{37}(1991)$ & Cross sectional & Allopurinol & "Lens changes" & $\begin{array}{l}53 \text { gout patients from gout clinic. All } \\
\text { on } 300 \text { mg daily for at least } 18 \\
\text { months. High prevalence }(25 \%) \text { of } \\
\text { thinning of clear zone of lens. } 12 \% \\
\text { with cataracts }\end{array}$ & $\begin{array}{l}\text { Background incidence not stated. No } \\
\text { statistical analysis }\end{array}$ \\
\hline Leske $^{38}(1991)$ & Case-control & $\begin{array}{l}\text { Allopurinol } \\
\text { Oral steroids }\end{array}$ & $\begin{array}{l}\text { Cataracts (various } \\
\text { types) }\end{array}$ & $\begin{array}{l}945 \text { cases, } 435 \text { controls in eye } \\
\text { hospital. Investigated nutrition, } \\
\text { medical history, and other risk } \\
\text { factors. Logistic regression gave } \\
\text { adjusted ORs of } 1.56 \text {, diabetes; } 5.83 \text {, } \\
\text { oral steroids; } 2.48 \text {, allopurinol }\end{array}$ & $\begin{array}{l}\text { "Lens opacities case control study". } \\
\text { Major study }\end{array}$ \\
\hline Davis $^{39}(1997)$ & Cross sectional & Cidofovir & $\begin{array}{l}\text { Iritis and } \\
\text { hypotonia }\end{array}$ & $\begin{array}{l}\text { Of } 43 \text { patients with CMV retinitis, } \\
26 \% \text { developed iritis. Impaired visual } \\
\text { acuity occurred in } 5 \text { eyes }\end{array}$ & $\begin{array}{l}\text { Iritis more likely to occur in diabetics } \\
(\mathrm{p}<0.05)\end{array}$ \\
\hline Pfefferman $^{40}(1977)$ & Cross sectional & Prednisolone & Cataracts & $\begin{array}{l}78 \text { renal transplant patients. } 2 / 78 \\
\text { with severe diabetic retinopathy. } 20 \\
\text { controls. Correlation of cumulative } \\
\text { prednisolone dose with cataracts. No } \\
\text { statistics }\end{array}$ & $\begin{array}{l}\text { Haemodialysis duration, age, and daily } \\
\text { prednisolone dose not correlated with } \\
\text { cataract }\end{array}$ \\
\hline Cumming $^{41}(1997)$ & Cross sectional & Inhaled steroids & Cataracts & $\begin{array}{l}3654 \text { volunteers. Assessed diabetes, } \\
\text { hypertension, inhaled and oral steroid } \\
\text { use. Groups similar for sex, smoking, } \\
\text { and diabetes. Ordinal regression gave } \\
\text { adjusted ors of } 1.8\end{array}$ & $\begin{array}{l}\text { Some missing data on steroid usage } \\
\text { and confounders }\end{array}$ \\
\hline Garbe $^{42}(1997)$ & Case-control & $\begin{array}{l}\text { Oral } \\
\text { glucocorticoids }\end{array}$ & $\begin{array}{l}\text { Open angle } \\
\text { glaucoma and } \\
\text { ocular } \\
\text { hypertension }\end{array}$ & $\begin{array}{l}\text { Elderly population. } 9793 \text { cases on } \\
\text { treatment. } 38325 \text { controls- } \\
\text { randomly selected eye patients. } \\
\text { Logistic regression adjusted for } \\
\text { various confounders including } \\
\text { diabetes. Adjusted odds ratio was } \\
1.41 \text { for current users of steroids for } \\
\text { either glaucoma or ocular } \\
\text { hypertension }\end{array}$ & $\begin{array}{l}\text { Weak association but significant. } \\
\text { Authors suggest regular IOP } \\
\text { monitoring required in elderly on long } \\
\text { term steroids }\end{array}$ \\
\hline Yablonski $^{43}(1978)$ & $\begin{array}{l}\text { Intervention } \\
\text { study }\end{array}$ & $\begin{array}{l}\text { Dexamethasone } \\
\text { (topical) }\end{array}$ & Cataracts & $\begin{array}{l}11 \text { diabetics. One eye treated with } \\
0.1 \% \text { eye drops. } 9 \text { showed pathology } \\
\text { ( } 4 \text { requiring surgery) in treated eyes. } \\
1 \text { patient developed cataracts in } \\
\text { untreated eye }\end{array}$ & Difference was significant $(\mathrm{p}<0.005)$ \\
\hline
\end{tabular}


Table 3 Summary of reported drug induced ocular reactions

\begin{tabular}{|c|c|c|}
\hline Drug & Reaction & Comments \\
\hline amiodarone & optic neuropathy & sudden visual loss \\
\hline chlorothiazide & oculomotor nerve palsy & \\
\hline indapamide & cataract & bilateral \\
\hline chlorpropamide & optic neuropathy & visual loss \\
\hline glibenclamide & $\begin{array}{l}\text { (1) myopia, (2) hyperopia, (3) lens } \\
\text { changes }\end{array}$ & vision returned to normal on stopping therapy \\
\hline interferon & retinopathy & mostly asymptomatic \\
\hline streptokinase & retinal/vitreous haemorrhage & marked reduction in vision \\
\hline warfarin & vitreous haemorrhage & blindness \\
\hline erythropoietin & visual hallucinations & mechanism uncertain \\
\hline isoniazid & optic neuropathy & vision normalised after stopping \\
\hline ethambutol & optic neuropathy & \\
\hline phenformin + ethanol & blindness & secondary to lactic acidosis following drinking binge \\
\hline oral contraceptive & $\begin{array}{l}\text { (1) diabetic retinopathy, (2) colour } \\
\text { vision disturbance }\end{array}$ & (1) no adverse effect (2) mechanism uncertain \\
\hline phenothiazines & cataracts & large study-strong association \\
\hline allopurinol & cataracts & $\begin{array}{l}\text { risk independent of diabetes in one study but significant } \\
\text { factor in another }\end{array}$ \\
\hline cidofovir & iritis + hypotony & iritis more likely in diabetes \\
\hline scopolamine & acute angle glaucoma & predictable from transdermal patch \\
\hline steroids (oral) & $\begin{array}{l}\text { open angle glaucoma and ocular } \\
\text { hypertension }\end{array}$ & large study confirmed increased risk \\
\hline steroids (oral) & cataracts & increased risk \\
\hline steroids (eye drops) & cataracts & small study but significant risk \\
\hline steroids (inhaled) & cataracts & increased risk \\
\hline $\mathrm{OKT}_{3}$ & reduced visual acuity & uncertain mechanism \\
\hline
\end{tabular}

least one other study which did include diabetes as above. Table 3 summarises the reactions obtained, listed according to drug or drug group. In addition, the review articles mentioned a number of side effects not specifically occurring in diabetes and included reduced visual acuity with cisplatin and cytarabine, papilloedema with ketoconazole, and retinopathy with chloroquine. ${ }^{810}$

JOURNAL TYPE

Of the 45 relevant journals, seven (15.6\%) were specialist medical, 11 (24.4\%) were general medical, $25(55.6 \%)$ were ophthalmological, with one $(2.2 \%)$ pharmaceutical and one $(2.2 \%)$ diabetes related journals. Thus, over half of the journals would, most probably, be read by ophthalmologists only.

BNF SPC CROSS REFERENCING

Table 4 displays the results of the cross check between the drug list and the BNF/SPC. Fewer side effects were reported for the datasheet because certain products were not listed in the SPC. $\mathrm{OKT}_{3}$ was not listed in either the $B N F$ or SPC.

\section{Discussion}

This literature search identified studies of all types. These are discussed in relation to ocular structure affected.

RETINA

Cross sectional studies suggested that oral contraceptive pill use does not have any effect on diabetic retinopathy. ${ }^{28}$ Interferon treat-

Table 4 Comparison of side effects obtained from literature search with those found in $B N F$ and datasheet

\begin{tabular}{lll}
\hline Category & Number in BNF (\%) & $\begin{array}{l}\text { Number in SPC } \\
\text { (datasheet) (\%) }\end{array}$ \\
\hline $\begin{array}{l}\text { A, complete agreement } \\
\text { B, partial agreement }\end{array}$ & $6(26)$ & $10(45)$ \\
$\begin{array}{l}\text { C, present in literature review } \\
\text { list but not in BNF/datasheet }\end{array}$ & $3(13)$ & $3(14)$ \\
Totals & $14(61)$ & $9(41)$ \\
\hline
\end{tabular}

ment for hepatitis C, however, does cause retinopathy. Several case reports were identified documenting this. The funduscopic appearances have some features in common with diabetic retinopathy suggesting that interferon retinopathy is also the result of a microangiopathy. ${ }^{32}$ The suggestion was made that the retinopathy was worse in patients with diabetes. This was found to be statistically significant in another study of 63 patients with hepatitis treated with interferon where $11 / 12$ $(92 \%)$ of patients with diabetes developed evidence of retinopathy although it was asymptomatic in the majority. ${ }^{33}$ Treatment with intravenous cidofovir for cytomegalovirus retinitis caused iritis in $26 \%$ of 43 patients. ${ }^{39}$ The risk of iritis appeared to be increased in patients with diabetes.

Lakowski and Morton describe colour vision changes that occur with diabetes and also with oral oestrogen usage. ${ }^{27}{ }^{44}$ Steinberg et al described visual hallucinations in dialysis patients after erythropoietin. ${ }^{31}$ Risk factors for hallucinations on this treatment included diabetic retinopathy or cataracts. Inhibition of oxidative metabolism in the retina was thought to be responsible for blindness which occurred in a diabetic patient with lactic acidosis following phenformin treatment. ${ }^{46}$

LENS AND PUPIL

The effects of glucocorticoids on the eye were examined in a number of studies. Risk of cataract was examined in a large matched cohort study by Isaac et al who found that risk was increased with use of systemic steroids, phenothiazines, antidiabetic agents, and benzodiazepines. ${ }^{35}$ It has recently been claimed that use of inhaled steroids is associated with the development of cataracts. ${ }^{12}{ }^{41}$ Topical dexamethasone eye drops appear to cause cataracts. ${ }^{43}$ The relation between cataract and allopurinol use has also been examined. Studies by Liu et $a l$ and Leske et al did find a relation while in the study by Clair et al no significant increase in 
odds ratio was observed. ${ }^{36-38}$ The presence of diabetes appears to increase the risk.

Lightman et al suggested that the modern, more potent sulphonylureas cause changes within the lens altering refraction. ${ }^{17}$ This phenomenon has previously been described by Keller. ${ }^{45}$ Hyperglycaemia in diabetes results in sorbitol accumulation in the lens, along with other diabetes specific metabolic changes at the cellular level. D'Arcy reported a single case of glibenclamide induced accommodation paralysis and cited older references to sulphonylurea induced myopia. ${ }^{16}$ It is suggested that there is swelling of the lens and ciliary body with forward displacement of the lens-iris diaphragm. Topical ophthalmic and oral glucocorticoids may cause glaucoma. ${ }^{42}$

The effect of pupillary dilatation on visual acuity is important in relation to driving. It is now policy in most diabetes units that diabetic patients should undergo mydriasis before funduscopy. Tropicamide is generally used for its short duration of action, but despite this a recent study has shown that a minority of patients have binocular visual acuity insufficient to meet the legal requirement for driving 1 hour after mydriasis. ${ }^{47}$ Thus patients should now be advised (usually at the previous visit) not to drive themselves after mydriasis. The risk of precipitating acute glaucoma is considered small enough to be acceptable. Of the various possible adverse outcomes of pupil dilatation, recent experience is that the alternative-missing sight threatening retinopathy-carries the greatest medicolegal risk.

OPTIC NERVE

Wymore and Carter described a case of optic neuropathy with chlorpropamide which recovered with withdrawal of the drug and cited two other examples from the literature. ${ }^{15}$ This adverse effect is not mentioned in the $B N F$. Elsewhere, Sedwick discusses the possible relation between amiodarone induced and ischaemic optic neuropathy in a diabetic patient. ${ }^{19}$ Optic neuropathy is well recognised with ethambutol. The search identified a diabetic patient with tuberculosis in whom isoniazid was thought to be the predominant factor. ${ }^{25}$ These authors cite 13 other cases of optic neuropathy due to isoniazid.

\section{VITREOUS}

Several reports described vitreous haemorrhage in patients given warfarin, streptokinase, or recombinant tPA. ${ }^{23}{ }^{24}$ Since these treatments are commonly used, generally without detailed retinal assessment, this adverse effect is likely to be substantially more common than generally realised. Physicians perhaps do not always appreciate that haemorrhage can occur despite laser treatment if the new vessels have not fully regressed. One report described bilateral vitreous haemorrhage requiring vitrectomy in a non-diabetic patient following tPA. ${ }^{48}$ There is evidence that aspirin is not contraindicated in diabetic patients with proliferative retinopathy. $^{7}$
RETINAL ARTERY AND VEIN

Greven et al described retinal artery occlusions in 21 patients under the age of $40 .^{30}$ The majority had one or more risk factors, two had diabetes, and five were taking oral contraceptive agents.

Diabetes is a risk factor for retinal vein occlusion (RVO). ${ }^{49}$ Kirwan et al found an associaton between oral contraceptive use and RVO in women aged under $35 .{ }^{50}$ Hormone replacement therapy with lower doses of oestrogens did not appear to be a risk factor. They concluded that RVO is a contraindication to use of oral contraception.

GENERAL CONCLUSION

Of particular interest was whether our approach would identify new adverse reactions. This was likely to come from individual case reports. Single examples must be considered unconfirmed. For example, the potential for thiazide treatment to cause oculomotor palsy and cataracts has not been reported elsewhere. ${ }^{13}{ }^{14}$ However, chlorpropamide optic neuropathy and lens changes due to second generation sulphonylureas both appeared in more than one report but do not seem to have made it into the reference works. Such reports are by their nature anecdotal but the prevalence of such reactions is likely to be higher than realised. Thus a system of prospective surveillance is needed.

INFORMATION AVAILABILITY

To estimate how much of this information is readily available to physicians we determined how many of them were listed in the $B N F$ and the data sheets. From Table 4, the data sheets were slightly more accurate than the $B N F$ with $45 \%$ and $26 \%$ respectively in complete agreement with the literature review list. This is not surprising because the datasheet, which outlines the licensed indications for a specific drug, is generally much more detailed than the equivalent $B N F$ entry. The most striking result is that between $41 \%$ and $61 \%$ of the side effects from the review were not present in the $B N F$ or datasheet. It is uncertain whether this reflects lack of awareness of the report or delay before new side effects are included, or an editorial opinion that the associations between drug and effect was not strong enough to merit inclusion.

Approximately one quarter of all reactions were reported in general medical journals. This means that $75 \%$ of the reactions would be unlikely to be read by physicians who are responsible for prescribing the majority of these drugs. Although the reactions cited in Table 3 are mostly rare, unless the general population of prescribers are made aware of these suspicions, their true incidence may never be known. One possible solution is to ensure that the $B N F$ should include more of these reactions. However, as discussed above, this is not without its problems. There is a need, therefore, for an early warning system where prescribers can share their experiences of potential ocular reactions. Perhaps the first stage of this process should involve the setting 
up of a UK registry of drug induced ocular side effects.

Financial support for this study was provided by the NHS Wales Office of Research and Development.

1 Klein RK. The epidemiology of diabetic retinopathy. In: Pickup JC, Williams G, eds. Chronic complications of diabetes. 1st ed. London: Blackwell Scientific Publications, diabetes. 1st ed.

2 Dornan T, Vernon S. Diabetes and the eye. In: Tattersall RB, Gale AM, eds. Diabetes clinical management. London: Churchill Livingstone, $1990 \cdot 263-80$

3 Fraunfelder FT. National registry of drug-induced ocular side effects. Am $\mathcal{F}$ Ophthalmol 1990;110:426-7.

4 British National Formulary. 35th ed. London: Pharmaceutical Press, 1998

5 ABPI Compendium of data sheets and summaries of product characteristics. London: Datapharm Publications, 1998.

6 The Cochrane Library. 2nd ed. Oxford: Update Software, 1998.

7 Wong Jun Shyan. Anticoagulation, antiplatelets and ocular haemorrhage. Singapore Med F 1997;38:279.

8 Fraunfelder FT. Drug-induced ocular side effects. Folia Ophthalmol fpn 1996;47:770-3.

9 Paterson CA. Effects of drugs on the lens. Int Ophthalmol Clin 1971;11:63-97.

10 Novack GD. Ocular toxicology. Curr Opin Ophthalmol 1994; 5:110-14.

11 Renfro L, Snow JS. Ocular effects of topical and systemic steroids. Dermatol Clin 1992;10:505-12.

12 Chylack LT. Cataracts and inhaled corticosteroids. N Engl $\mathcal{F}$ Med 1997;337:46-8.

13 Miller NR, Moses H. Transient oculomotor nerve palsy. Association with thiazide- induced glucose intolerance. FAMA 1978;240:1887-8.

14 Sponsel WE, Rapoza PA. Posterior subcapsular cataract associated with indapamide therapy. Arch Ophthalmol 1992;110:454.

15 Wymore J, Carter JE. Chlorpropamide-induced optic neuropathy. Arch Intern Med 1982;142:381.

16 D'Arcy PF. Drug reactions and interactions. Int Pharm $f$ 1989;3:220-2.

17 Lightman JM, Townsend JC, Selvin GJ. Ocular effects of second generation oral hypoglycemic agents (see comments). F Am Optom Assoc 1989;60:849-53.

18 Hamill MB, Suelflow JA, Smith JA. Transdermal scopolamine delivery system (Transderm-V) and acute anglelamine delivery system (Transderm-V) and acute a

19 Sedwick LA. Getting to the heart of visual loss: when cardiac medication may be dangerous to the optic nerves (clinical conference). Surv Ophthalmol 1992;36:366-72.

20 Zenimaru T, Hirokawa H, Takeda M, et al. Aggravation of diabetic retinopathy in a case under interferon therapy. Rinsho Ganka 1997;51:1555-8.

21 Filipovic T, Bujanic Cuculic S, et al. (Optic nerve damage caused by administration of ethambutol). Lijec Vjesn 1997 119:273-4.

22 Sorensen PN. Transitory blindness during ethanol and phenethylbiguanide induced lactic acidosis in a subject 1977;55:177-82.

23 Maddox K. Blindness due to an anticoagulant (letter). Med F Aust 1977;1:420.

24 Caramelli B, Tranchesi B Jr, Gebara OC, et al. Retinal haemorrhage after thrombolytic therapy (letter). Lance 1991;337:1356-7.

25 Jimenez Lucho VE, del Busto R, Odel J. Isoniazid and ethambutol as a cause of optic neuropathy. Eur F Respir Dis $1987 ; 71: 42-5$.
26 Dukar O, Barr CC. Visual loss complicating OKT3 monoclonal antibody therapy. Am 7 Ophthalmol 1993;115:781-5.

27 Lakowski R, Morton A. The effect of oral contraceptives on Lakowski R, Morton A. The effect of oral contraceptives on
colour vision in diabetic women. Can $\mathcal{f}$ Ophthalmol 1977;12:89-97.

28 Garg SK, Chase HP, Marshall G, et al. Oral contraceptives and renal and retinal complications in young women with insulin-dependent diabetes mellitus. FAMA 1994;271: 1099-102.

29 Klein BE, Moss SE, Klein R. Oral contraceptives in women with diabetes. Diabetes Care 1990;13:895-8.

30 Greven CM, Slusher MM, Weaver RG. Retinal arterial occlusions in young adults. Am f Ophthalmol 1995;120: 776-83.

31 Steinberg H, Saravay SM, Wadhwa N, et al. Erythropoietin and visual hallucinations in patients on dialysis. Psychosomatics 1996;37:556-63.

32 Chen LL, Onishi A, Kawano C, et al. Interferon-associated retinopathy in patients receiving systemic interferon therapy. Folia Ophthalmol fpn 1996;47:1263-8.

33 Kawano T, Shigehira M, Uto H, et al. Retinal complications during interferon therapy for chronic hepatitis C. Am $\mathcal{F}$ Gastroenterol 1996;91:309-313.

34 Ramamurthy S. Thrombolysis in dialysis patients with diabetic hemorrhagic retinopathy. Fedrip Database National Technical Information Service (NTIS), 1997.

35 Isaac NE, Walker AM, Jick $\mathrm{H}$, et al. Exposure to phenothiazine drugs and risk of cataract. Arch Ophthalmol 1991;109:256-60.

36 Clair WK, Chylack LT Jr, Cook EF, et al. Allopurinol use and the risk of cataract formation. $\mathrm{Br} \mathcal{F}$ Ophthalmol 1989;73:173-6.

37 Liu CS, Leonard TJ, Brown NA. The lens opacities case-control study. Arch Ophthalmol 1991;109:1635-6.

38 Leske MC, Chylack LT Jr, Wu SY. The lens opacities casecontrol study:risk factors for cataract. Arch Ophthalmol 1991;109:244-51.

39 Davis JL, Taskintuna I, Freeman WR, et al. Iritis and hypotony after treatment with intravenous cidofovir for cytomegalovirus retinitis (see comments). Arch Ophthalmol 1997; 115:733-7.

40 Pfefferman R, Gombos GM, Kountz SL. Ocular complications after renal transplantation. Ann Ophthalmol 1977;9: 467-73.

41 Cumming RG, Mitchell P, Leeder SR. Use of inhaled corticosteroids and the risk of cataracts. $N$ Engl $\mathcal{F} \mathrm{Med}$ 1997;337:8-14.

42 Garbe E, LeLorier J, Boivin JF, et al. Risk of ocular hypertension or open-angle glaucoma in elderly patients on oral glucocorticoids. Lancet 1997;350:979-82.

43 Yablonski ME, Burde RM, Kolker AE, et al. Cataracts induced by topical dexamethasone in diabetics. Arch Ophthalmol 1978;96:474-6.

44 Lakowski R, Morton A. Acquired colour losses and oral contraceptives. Mod Probl Ophthalmol 1978;19:314-18.

45 Keller JT. Second generation oral hypoglycemic agents (letter; comment). F Am Optom Assoc 1991;62:513-14.

46 Goldberg LD, Alterman SL. Concurrent hypoglycemia and lactic acidosis in a diabetic treated with chlorpropamide and phenformin. South Med f 1973;66:190-2.

47 Jude EB, Ryan B, O'Leary BM, et al. Pupillary dilatation and driving in diabetic patients. Diabetic Med 1998;15:1437.

48 Grekos ZG, Schocken DD. Bilateral vitreous hemorrhages as a consequence of thrombolytic therapy successfully treated with vitrectomy in a patient without diabetes. $\mathrm{Am}$ Heart 7 1995;130:611-12.

49 Eye Disease Case Control Study Group. Risk factors for central retinal vein occlusion. Arch Ophthalmol 1996;114: $545-54$

50 Kirwan JF, Tsaloumas MD, Vinall $\mathrm{H}$, et al. Sex hormone preparations and retinal vein occlusion. Eye 1997;11:53-6. 